\title{
IMPLEMENTASI MODEL PEMBELAJARAN ACTIVE LEARNING TIPE PENGADILAN MAJELIS HAKIM DALAM PEMBELAJARAN PJOK MATERI NARKOBA DAN PELECEHAN SEKSUAL PADA SISWA KELAS VI SDN TANGGULANGIN I
}

\author{
Moch. Sunaryo \\ Sekolah Dasar Negeri (SDN) Tanggulangin I Tuban, Indonesia \\ Sunaryo.moch@gmail.com
}

\begin{abstract}
Penelitian ini bertujuan untuk Ingin mengetahui peningkatan prestasi belajar mata pelajaran PJOK setelah diterapkannya model pembelajaran active learning tipe pengadilan majelis hakim; dan mengetahui aktivitas belajar siswa kelas VI SDN Tanggulangin I Tahun Pelajaran 2015/2016 dengan diterapkannya model pembelajaran active learning tipe pengadilan majelis hakim. Penelitian ini menggunakan penelitian tindakan (action research) sebanyak 2 (dua) putaran. Setiap putaran terdiri dari empat tahap yaitu: rancangan, kegiatan dan pengamatan, refleksi, dan refisi. Sasaran penelitian ini adalah siswa kelas VI SDN Tanggulangin I tahun pelajaran 2015/2016. Data yang diperoleh berupa hasil tes formatif, dan lembar observasi kegiatan belajar mengajar. Dari hasil analis didapatkan bahwa prestasi belajar siswa mengalami peningkatan yang signifikan, dari siklus I sampai siklus II yaitu: siklus I $(77,78 \%)$ dan siklus II $(94,44 \%)$ dengan nilai rata-rata siklus I $(79,56)$ dan siklus II $(86,00)$. Pada akhirnya, model pembelajaran active learning tipe pengadilan majelis hakim dapat berpengaruh positif terhadap prestasi belajar siswa kelas VI SDN Tanggulangin I tahun pelajaran 2015/2016, serta model pembelajaran ini dapat digunakan sebagai salah satu alternatif pembelajaran mata pelajaran PJOK.
\end{abstract}

Keyword: Pembelajaran PJOK; Active Learning; Pengadilan Majelis Hakim Copyright (C) 2017 Madrasah Jurnal Pendidikan dan Pembelajaran Dasar. All Right Reserved

\section{A. PENDAHULUAN}

Pendidikan Jasmani, olahraga dan kesehatan merupakan media untuk mendorong pertumbuhan fisik, perkembangan psikis, keterampilan motorik, pengetahuan dan penalaran, penghayatan nilai-nilai (sikap mental-emosional-sportivitas-spiritual-sosial). Di samping itu pendidikan jasmani merupakan salah satu mata pelajaran wajib di sekolah termasuk di Sekolah Dasar, karena pendidikan jasmani masuk dalam kurikulum pendidikan. Pendidikan jasmani merupakan bagian integral dari proses pendidikan secara total. Tujuan Pendidikan Jasmani untuk mengembangkan kebugaran fisik, mental, emosional dan sosial melalui kegiatan fisik. Rusli Lutan (2009:30), pendidikan jasmani merupakan bagian integral dari pendidikan keseluruhan yang bertujuan meningkatkan individu secara organik, neuromuskuler, intelektual dan emosional melalui aktivitas jasmani. Sedangkan guru selaku motivator dan fasilitator, memiliki peranan penting dalam memberikan arti dan makna pembelajaran Penjas dan olahraga sebagai sarana atau alat.

Kenyataan di lapangan tidak dapat di pungkiri bahwa PJOK terkadang tidak digemari siswa, apalagi guru pendidikan jasmani mengajar dengan monoton dan kurang

Vol. 9 No. 2, Juni 2017

Madrasah homepage: http://ejournal.uin-malang.ac.id/index.php/madrasah/index 
bervariasi, maka anak akan cepat jemu dan malas beraktivitas. Padahal titik sentral yang harus dicapai setiap kegiatan belajar mengajar adalah tercapainya tujuan pengajaran. Apapun yang termasuk perangkat program pengajaran dituntut secara mutlak untuk menunjang tercapainya tujuan. Guru tidak dibenarkan mengajar dengan kemalasan. Anak didikpun diwajibkan mempunyai kreatifitas yang tinggi dalam belajar, bukan selalu menanti perintah guru. Kedua unsur manusiawi ini juga beraktivitas tidak lain karena ingin mencapai tujuan secara efektif dan efisien.

Secara substansi salah satu tujuan pengajaran PJOK adalah memahami konsep aktivitas jasmani dan olahraga di lingkungan yang bersih sebagai informasi untuk mencapai pertumbuhan fisik yang sempurna, pola hidup sehat dan kebugaran, terampil, serta memiliki sikap yang positif. Seiring dengan maraknya peredaran narkoba dan tindak pidana pelecehan seksual akhir-akhir ini sangat mengkhawatirkan bagi kehidupan di masyarakat. Untuk menumbuhkembangkan sikap yang positif pada diri siswa perlu pembekalan pengetahuan yang mendalam tentang narkoba dan pelecehan seksual. Sehingga siswa dapat memami substansi narkoba dan pelecehan seksual serta mengenal cara menolak ajakan menggunakan narkoba dan tindak pidana pelecehan seksual.Di sisi lain ditemukan fakta bahwa prestasi belajar siswa kelas VI SDN Tanggulangin I materi narkoba dan pelecehan seksual masih sangat kurang. Hal ini dapat terbukti bahwa dari hasil tes tulis yang dilakukan oleh penulis tentang materi narkoba dan pelecehan seksual ada beberapa siswa yang belum tuntas dalam pembelajaran pokok bahasan tersebut.

Pada pembelajaran PJOK materi narkoba dan pelecehan seksual, sebelumnya peneliti telah menggunakan metode ceramah, tanya jawab dan penugasan, namun hal tersebut masih belum memberikan hasil yang memuaskan dengan perolehan nilai siswa seperti pada grafik 1 di bawah ini.

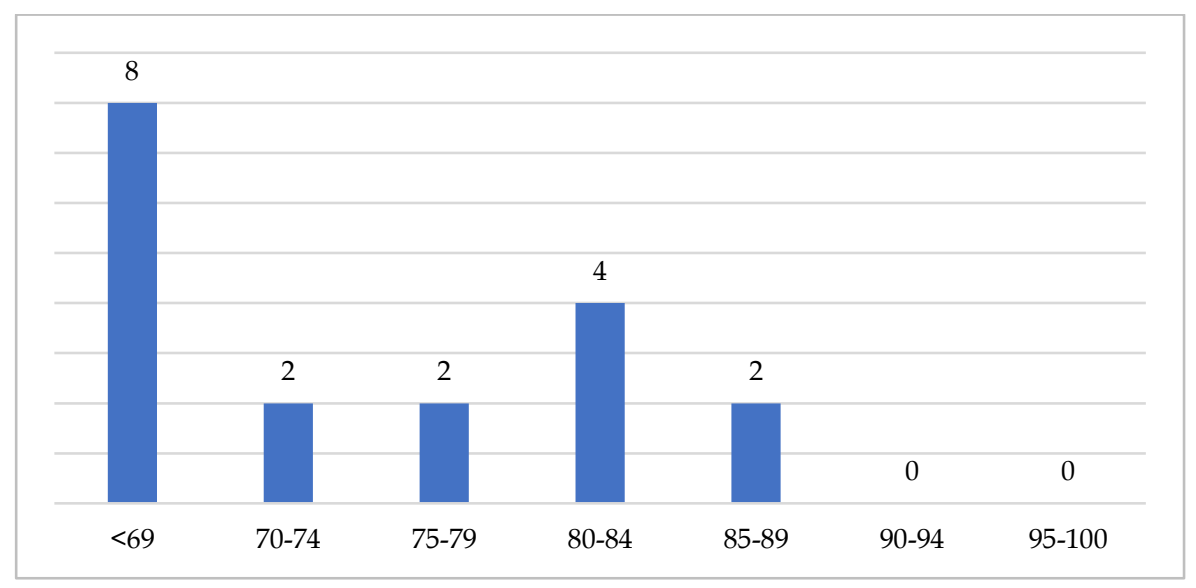

Grafik A.1 Nilai Siswa Pra Siklus

Dari data di atas dapat simpulkan bahwa ketuntasan siswa dalam pembelajaran PJOK masih rendah atau tidak signifikan kalau menggunakan metode ceramah, tanya jawab dan tugas untuk meningkatkan kemampuan siswa dalam hal pemahaman materi narkoba dan pelecehan seksual.

Dalam rangka meningkatkan kualitas hasil belajar PJOK yang lebih baik, dapat dimulai dengan memilih strategi belajar yang tepat. Menurut Iskandarwassid dan Dadang Sunendar (2009:168) agar tujuan pembelajaran dapat tercapai maksimal, maka diperlukan strategi pembelajaran yang tepat. Adakalanya tujuan pembelajaran tidak tercapai karena guru kurang mampu memilih strategi pembelajaran yang tepat untuk anak didiknya.

Vol. 9 No. 2, Juni 2017

Madrasah homepage: http://ejournal.uin-malang.ac.id/index.php/madrasah/index 


\section{MADRASAH}

Jurnal Pendidikan dan Pembelajaran Dasar

p ISSN: 1979-5599 | e ISSN: 2502-194X

P a g e

Strategi pembelajaran yang baik bertumpu pada pemilihan pendekatan dan metode pembelajaran yang tepat. Metode mengajar merupakan cara yang digunakan guru dalam kegiatan pembelajaran dan juga merupakan usaha untuk mencapai tujuan pembelajaran. Kegiatan pembelajaran akan kurang berarti bila tidak ditunjang dengan metode yang tepat. Prestasi dan motivasi belajar siswa terhadap suatu pelajaran menjadi kurang baik salah satu penyebabnya adalah penyampaian materi yang kurang menarik minat siswa, sehingga tujuan pembelajaran untuk melatih cara berfikir secara sistematis, logis, kritis, kreatif dan konsisten tidak tercapai secara maksimal.

Untuk meningkatkan kualitas proses dan hasil dalam pembelajaran PJOK di SDN Tanggulangin I, penulis mencoba menerapkan model pembelajaran active learning tipe pengadilan majelis hakim. Pada dasarnya, model active learning tipe pengadilan majelis hakim merupakan metode pembelajaran yang memanfaatkan pengadilan bohongbohongan, lengkap dengan saksi, jaksa penuntut, pembela, anggota pengadilan dan lainlain. Ini merupakan metode yang baik untuk memicu "belajar berbeda pendapat" yaitu belajar dengan secara efektif mengemukakan sebuah sudut pandang dan menentang pendapat yang sebaliknya. Dimana guru memberikan kepada para siswa waktu untuk berpikir dan merespons serta saling bantu satu sama lain. Sehingga dengan model tersebut siswa akan mudah mencurahkan ide dan pengalaman yang telah dia miliki ke dalam proses persidangan yang mereka lakukan.

\section{B. TINJAUAN PUSTAKA}

\section{Hakikat Pembelajaran PJOK}

Pendidikan Jasmani Olahraga dan Kesehatan merupakan salah satu mata pelajaran yang dilaksanakan pada jenjang pendidikan dasar, menengah, bahkan pada pendidikan tinggi. Tujuan Pendidikan Jasmani yaitu untuk mengembangkan aspek kebugaran jasmani, keterampilan gerak, keterampilan berpikir kritis, keterampilan sosial, penalaran, stabilitas emosional, tindakan moral dan aspek pola hidup sehat. (Permendiknas No.22 Tahun 2006:194).

Pendidikan jasmani adalah suatu proses pembelajaran melalui aktivitas jasmani yang didesain untuk meningkatkan kesegaran jasmani, membangun ketrampilan motorik, pengetahuan dan perilaku hidup sehat dan aktif, dan sikap sportif, serta kecerdasan emosi, (Depdiknas 2004:2).

Pendidikan jasmani merupakan proses interaksi antara peserta didik dengan lingkungan, melalui aktivitas jasmani yang dikelola secara sistemati untuk membentuk manusia Indonesia seutuhnya, Sukintaka (1992:24). Berdasarkan beberapa teori di atas pendidikan jasmani olahraga dan kesehatan merupakan suatu proses pembelajaran interaksi antara peserta didik dengan lingkungan melalui aktvitas jasmani yang dikelola secara sistematis untuk membentuk manusia Indonesia seutuhnya.

\section{Pengertian Prestasi Belajar}

Menurut Kamus Umum Bahasa Indonesia, pengertian prestasi adalah hasil yang telah dicapai (dari yang telah diakukan, dikerjakan, dan sebagainya) (1995:787). Sedangkan menurut Saiful Bahri Djamarah (1994:20-21) bahwa prestasi adalah apa yang telah dapat diciptakan, hasil pekerjaan, hasil yang menyenangkan hati yang diperoleh dengan jalan keuletan kerja. Dalam buku yang sama Nasrun harahap, berpendapat bahwa prestasi adalah penilaian pendidikan tentang perkembangan dan kemajuan siswa berkenaan dengan penguasaan bahan pelajaran yang disajikan kepada siswa. Dari pengertian di atas

Vol. 9 No. 2, Juni 2017

Madrasah homepage: http://ejournal.uin-malang.ac.id/index.php/madrasah/index 
dapat diambil kesimpulan bahwa prestasi adalah hasil dari suatu kegiatan seseorang atau kelompok yang telah dikerjakan, diciptakan dan menyenangkan hati yang diperoleh dengan jalan bekerja.

Selanjutnya untuk memahami pengertian tentang belajar berikut dikemukakan beberapa pengertian belajar diantaranya menurut Slameto (2003:2) dalam bukunya Belajar dan faktor-faktor yang mempengaruhinya bahwa belajar ialah suatu usaha yang dilakukan seseorang untuk memperoleh suatu perubahan tingkah laku yang baru secara keseluruhan, sebagai hasil pengalamannya sendiri dalam interaksi dengan lingkungannya.

Muhibbin Syah (2000:136) bahwa belajar adalah tahapan perubahan seluruh tingkah laku individu yang relative menetap sebagai hasil pengalaman dan interaksi dengan lingkungan yang melibatkan proses kognitif. Begitu juga menurut James Whitaker yang dikutip oleh Wasty Soemanto (1990:98-99), belajar adalah proses dimana tingkah laku ditimbulkan atau diubah melalui latihan dan pengalaman.

Berdasarkan beberapa pendapat di atas bahwa belajar merupakan kegiatan yang dilakukan secara sadar dan rutin pada seseorang sehingga akan mengalami perubahan secara individu baik pengetahuan, keterampilan, sikap dan tingkah laku yang dihasilkan dari proses latihan dan pengalaman individu itu sendiri dalam berinteraksi dengan lingkungannya.

Winkel dalam Sunarto (1996:162) mengatakan bahwa "prestasi belajar adalah suatu bukti keberhasilan belajar atau kemampuan seorang siswa dalam melakukan kegiatan belajarnya sesuai dengan bobot yang dicapainya". Menurut Abu Ahmadi dan Widodo Supriyono (1990:130) prestasi belajar merupakan hasil interaksi antara berbagai faktor yang mempengaruhinya baik dari dalam diri (faktor internal) maupun dari luar (faktor eksternal) individu.

Berdasarkan beberapa batasan diatas, prestasi belajar dapat diartikan sebagai kecakapan nyata yang dapat diukur yang berupa pengetahuan, sikap dan keterampilan sebagai interaksi aktif antara subyek belajar dengan obyek belajar selama berlangsungnya proses belajar mengajar untuk mencapai hasil belajar

\section{Pengertian Hasil Belajar}

Di dalam istilah hasil belajar, terdapat dua unsur di dalamnya, yaitu unsur hasil dan unsur belajar. Hasil merupakan suatu hasil yang telah dicapai pebelajar dalam kegiatan belajarnya (dari yang telah dilakukan, dikerjakan, dan sebagainya), sebagaimana dijelaskan dalam Kamus Besar Bahasa Indonesia, (1995:787). Dari pengertian ini, maka hasil belajar adalah penguasaan pengetahuan atau keterampilan yang dikembangkan oleh mata pelajaran, lajimnya ditunjukkan dengan nilai tes atau angka nilai yang diberikan oleh guru.

Istilah hasil belajar mempunyai hubungan yang erat kaitannya dengan prestasi belajar. Sesungguhnya sangat sulit untuk membedakan pengertian prestasi belajar dengan hasil belajar. Ada yang berpendapat bahwa pengertian hasil belajar dianggap sama dengan pengertian prestasi belajar. Akan tetapi lebih dahulu sebaiknya kita simak pendapat yang mengatakan bahwa hasil belajar berbeda secara prinsipil dengan prestasi belajar. Hasil belajar menunjukkan kualitas jangka waktu yang lebih panjang, misalnya satu cawu, satu semester dan sebagainya. Sedangkan prestasi belajar menunjukkan kualitas yang lebih pendek, misalnya satu pokok bahasan, satu kali ulangan harian dan sebagainya.

Nawawi (1981:100) mengemukakan pengertian hasil adalah keberhasilan murid dalam mempelajari materi pelajaran di sekolah yang dinyatakan dalam bentuk nilai atau skor dari hasil tes mengenai sejumlah pelajaran tertentu.

Pendapat lain dikemukakan oleh Sadly (1977:904), yang memberikan penjelasan tentang hasil belajar sebagai berikut, "Hasil yang dicapai oleh tenaga atau daya kerja

Vol. 9 No. 2, Juni 2017

Madrasah homepage: http://ejournal.uin-malang.ac.id/index.php/madrasah/index 


\section{MADRASAH}

Jurnal Pendidikan dan Pembelajaran Dasar

p ISSN: 1979-5599 | e ISSN: 2502-194X

P a g e

seseorang dalam waktu tertentu", sedangkan Marimba (1978:143) mengatakan bahwa "hasil adalah kemampuan seseorang atau kelompok yang secara langsung dapat diukur".

Menurut Nawawi (1981:127), berdasarkan tujuannya, hasil belajar dibagi menjadi tiga macam, yaitu: a) Hasil belajar yang berupa kemampuan keterampilan atau kecapakan di dalam melakukan atau mengerjakan suatu tugas, termasuk di dalamnya keterampilan menggunakan alat; b) Hasil belajar yang berupa kemampuan penguasaan ilmu pengetahuan tentang apa yang dikerjakan; c) Hasil belajar yang berupa perubahan sikap dan tingkah laku.

\section{Pengertian Pembelajaran Active Learning}

Istilah active learning atau yang bisa disebut dengan pembelajaran aktif terdiri dari dua suku kata, yaitu pembelajaran dan aktif. Kata pembelajaran berasal dari kata dasar belajar yang mendapat awalan pe- dan akhiran -an. Menurut Muhibbin Syah (2000:92) belajar mempunyai arti tahapan perubahan seluruh tingkah laku individu yang relatif menetap sebagai hasil pengalaman dan interaksi dengan lingkungan yang melibatkan proses kognitif. Sedang menurut Sardiman, (2000:20-21) pengertian belajar dibagi dua, yaitu pengertian luas dan khusus. Dalam pengertian luas belajar dapat diartikan sebagai kegiatan psiko-fisik menuju perkembangan pribadi seutuhnya. Kemudian dalam arti sempit, belajar dimaksudkan sebagai usaha penguasaan materi ilmu pengetahuan yang merupakan sebagian kegiatan menuju terbentuknya kepribadian seutuhnya. Definisi dalam arti khusus inilah yang banyak dianut sekolah-sekolah.

Sedangkan aktif berasal dari bahasa Inggris, yaitu "active", yang mempunyai arti rajin, sibuk, giat. (W.J.S. Poerwadarminta, 2002:25). Sebagai suatu konsep, pembelajaran aktif adalah suatu proses kegiatan belajar mengajar yang subyek didiknya terlibat secara intelektual dan emosional, sehingga subyek didik betul-betul terlibat dalam malakukan kegiatan belajar.

Dalam pembelajaran aktif, siswa diposisikan sebagai inti dalam kegiatan belajar mengajar. Pembelajaran aktif adalah salah satu strategi belajar mengajar yang menuntut keaktifan dan partisipasi subyek didik secara optimal, sehingga siswa mampu mengubah tingkah lakunya secara efektif dan efisien (M. Dalyono, 1997:195).

Dari beberapa pendapat di atas, dapat disimpulkan, bahwa pembelajaran dapat berlangsung efektif manakala dalam suatu proses yang terjalin komunikasi yang aktif antara guru dan siswa dengan melibatkan aspek intelektual dan emosional. Dengan demikian, dapat dikatakan bahwa pembelajaran aktif adalah proses keterlibatan intelektual dan emosional peserta didik dalam proses belajar mengajar yang dapat memungkinkan terjadinya; (a) Proses asimilasi dan akomodasi dalam pencapaian pengetahuan; (b) Proses perbuatan serta pengalaman langsung terhadap umpan balik dalam pembentukan keterampilan; dan (c) Proses penghayatan serta internalisasi nilai-nilai dalam rangka pembentukan nilai dan sikap.

\section{Pembelajaran Tipe Pengadilan Majelis Hakim}

Tehnik ini memanfaatkan pengadilan bohong-bohongan, lengkap dengan saksi, jaksa penuntut, pembela, anggota pengadilan dan lain-lain. Ini merupakan metoda yang baik untuk memicu "belajar berbeda pendapat" yakni belajar dengan secara efektif mengemukakan sebuah sudut pandang dan menentang pendapat yang sebaliknya.

\section{a. Prosedur Pembelajaran Pengadilan Majelis Hakim}

1) Buatlah dakwaan yang akan membantu siswa mengetahui sisi-sisi yang berbeda dari sebuah persoalan. Contoh-contoh "kejahatan" yang bisa didakwakan kepada seseorang

Vol. 9 No. 2, Juni 2017

Madrasah homepage: http://ejournal.uin-malang.ac.id/index.php/madrasah/index 
atau kepada suatu benda adalah: orang berpendidikan atau orang biasa yang moralnya bobrok; buku kontroversial; teori yang tidak terbukti; nilal-nilal yang tidak memiliki manfaat; dan proses, hukum, atau institusi yang menyimpang.

2) Berikan peran kepada siswa. Tergantung pada jumlah siswa, anda dapat menggunakan semua atau beberapa dari peran berikut ini, pembela, saksi meringankan, jaksa penuntut umum, saksi memberatkan, panitera, hakim ketua, dan hakim anggota. Tiap peran bisa diisi oleh satu orang siswa atau satu tim. Anda bisa menetapkan sendiri jumlah majelis hakimnya

3) Berikan waktu kepada siswa untuk mempersiapkan diri. Ini bisa berlangsung dari beberapa menit hingga satu jam, tergantung pada kerumitan masalahnya.

4) Laksanakan pengadilan. Pertimbangkan untuk menggunakan aktivitas berikut ini: argumen pembuka, kasus yang diajukan oleh penuntut dan saksi, laporan singkat panitera persidangan, dan argumen penutup.

5) Lakukan pertimbangan hakim. Ini bisa dilakukan secara terbuka, agar semua siswa bisa mendengar bagaimana bukti ditimbang. Anggota non-hakim bisa diberi tugas untuk mendengarkan berbagai aspek kasus.

6) Variasi : (1) Perluas kegiatan dengan pentarafan pengadilan ulang; dan (2) Hilangkan pengadilan oleh majelis hakim dan gantikan pengadilan hanya oleh hakim.

\section{b. Langkah-langkah Pembelajaran Pengadilan Majelis Hakim}

Langkah-langkah pembelajarannya adalah sebagai berikut : (1) Guru menyusun/menyiapkan skenario persidangan yang akan ditampilkan; ((2) Menunjuk beberapa siswa untuk mempelajari skenario persidangan dalam waktu beberapa hari sebelum pelaksanaan Kegiatan Belajar Mengajar; (3) Guru membentuk kelompok siswa yang anggotanya 6 orang; (4) Memberikan penjelasan tentang kompetensi yang ingin dicapai; (5) Memanggil para siswa yang sudah ditunjuk untuk melakonkan skenario persidangan yang sudah dipersiapkan; (6) Masing-masing siswa berada di kelompoknya sambil mengamati skenario persidangan yang sedang diperagakan; (7) Setelah selesai ditampilkan, masing-masing siswa diberikan lembar kerja untuk membahas/memberi penilaian atas penampilan masing-masing kelompok; (8) Masing-masing kelompok menyampaikan hasil kesimpulannya; (9) Guru memberikan kesimpulan secara umum; (10) Evaluasi; dan (11) Penutup.

\section{METODOLOGI PENELITIAN}

Penelitian ini merupakan penelitian tindakan (action research), karena penelitian dilakukan untuk memecahkan masalah pembelajaran di kelas. Penelitian ini juga termasuk penelitian deskriptif, sebab menggambarkan bagaimana suatu teknik pembelajaran diterapkan dan bagaimana hasil yang diinginkan dapat dicapai.

Tempat penelitian adalah tempat yang digunakan dalam melakukan penelitian untuk memperoleh data yang diinginkan. Penelitian ini bertempat di SDN Tanggulangin I Kecamatan Montong Kabupaten Tuban. Waktu penelitian adalah waktu berlangsungnya penelitian atau saat penelitian ini dilangsungkan. Penelitian ini dilaksanakan pada bulan Februari-April 2016 Sedangkan subyek penelitian adalah siswa-siswi kelas VI SDN SDN Tanggulangin I Kecamatan Montong Kabupaten Tuban Tahun Pelajaran 2015/2016 pokok bahasan narkoba dan pelecehan seksual.

Sesuai dengan jenis penelitian yang dipilih, yaitu penelitian tindakan, maka penelitian ini menggunakan model penelitian tindakan dari Kemmis dan Taggart (dalam Sugiarti, 1997:6), yaitu berbentuk spiral dari sklus yang satu ke siklus yang berikutnya. Setiap siklus meliputi planning (rencana), action (tindakan), observation (pengamatan), dan

Vol. 9 No. 2, Juni 2017

Madrasah homepage: http://ejournal.uin-malang.ac.id/index.php/madrasah/index 


\section{MADRASAH}

Jurnal Pendidikan dan Pembelajaran Dasar

p ISSN: 1979-5599 | e ISSN: 2502-194X

P a g e

reflection (refleksi). Langkah pada siklus berikutnya adalah perncanaan yang sudah direvisi, tindakan, pengamatan, dan refleksi. Sebelum masuk pada siklus I dan II dilakukan tindakan pendahuluan yang berupa identifikasi permasalahan.

Metode pengumpulan data diperoleh melalui observasi, pengolahan metode pembelajaran, observasi aktivitas guru dan siswa, serta tes formatif. Instrument yang digunakan meliputi: silabus, RPP, lembar kegiatan siswa, lembar observasi pengolahan model pembelajaran active learning tipe pengadilan majelis hakim, lembar observasi aktivitas guru dan siswa, serta tes formatif yang disusun berdasarkan tujuan pembelajaran dengan analisis butir soal tes yang telah diuji validitas dan reliabilitas tiap soal, serta uji taraf kesukaran dan daya pembeda. Teknik analisis data yang digunakan yaitu teknik analisis deskriptif kualitatif.

Berdasarkan masalah tersebut maka yang merupakan variabel penelitian tindakan kelas ini adalah : (1) Variabel bebas adalah variabel yang mempengaruhi perubahan pada variabel terikat yaitu model pembelajaran active learning tipe pengadilan majelis hakim; dan (2) Variabel terikat adalah variabel yang dipengaruhi oleh variabel bebas yaitu tingkat penguasaan materi pokok bahasan narkoba dan pelecehan seksual.

Untuk menganalisis tingkat keberhasilan atau persentase keberhasilan siswa setelah proses belajar mengajar setiap putarannya dilakukan dengan cara memberikan evaluasi berupa soal tes tertulis pada setiap akhir putaran. Analisis ini dihitung dengan menggunakan statistik sederhana yaitu:

1. Untuk menilai ulangan atau tes formatif

Peneliti melakukan penjumlahan nilai yang diperoleh siswa, yang selanjutnya dibagi dengan jumlah siswa yang ada di kelas tersebut sehingga diperoleh rata-rata tes formatif dapat dirumuskan:

$$
\bar{X}=\frac{\sum X}{\sum N}
$$

Dengan $: \bar{X} \quad=$ Nilai rata-rata

$\Sigma X=$ Jumlah semua nilai siswa

$\Sigma \mathrm{N}=$ Jumlah siswa

2. Untuk ketuntasan belajar

Setiap siswa dikatakan tuntas belajarnya (ketuntasan individu) jika proporsi jawaban benar siswa $\geq 65 \%$, dan suatu kelas dikatakan tuntas belajarnya (ketuntasan klasikal) jika dalam kelas tersebut terdapat $\geq 85 \%$ siswa yang telah tuntas belajarnya (Depdikbud dalam Trianto, 2010: 241).

Tetapi, menurut Trianto (2010: 241) berdasarkan ketentuan KTSP penentuan ketuntasan belajar ditentukan sendiri oleh masing-masing sekolah yang dikenal dengan istilah kriteria ketuntasan minimal, dengan berpedoman pada tiga pertimbangan, yaitu: kemampuan setiap peserta didik berbeda-beda; fasilitas (sarana) setiap sekolah berbeda; dan daya dukung setiap sekolah berbeda. Maka dalam penelitian ini, sesuai dengan KKM mata pelajaran PJOK di sekolah tempat peneliti melakukan penelitian, maka ketuntasan individual adalah 70 dan ketuntasan secara klasikal adalah 85\%. berikut:

Untuk menghitung persentase ketuntasan belajar digunakan rumus sebagai

Vol. 9 No. 2, Juni 2017

Madrasah homepage: http://ejournal.uin-malang.ac.id/index.php/madrasah/index 


$$
P=\frac{\sum \text { Siswa.yang.tuntas.belajar }}{\sum \text { Siswa }} \times 100 \%
$$

3. Untuk lembar observasi

a. Lembar observasi pengelola model pembelajaran active learning tipe pengadilan majelis hakim.

Untuk menghitung lembar observasi pengelolaan model pembelajaran active learning tipe pengadilan majelis hakim digunakan rumus sebagai berikut:

$$
\overline{\mathrm{X}}=\frac{P 1+P 2}{2} \quad \text { Dimana } \mathrm{P} 1=\text { Pengamat } 1 \text { dan } \quad \mathrm{P} 2=\text { Pengamat } 2
$$

b. Lembar observasi aktifitas guru dan siswa

Untuk menghitung lembar observasi aktifitas guru dan siswa digunakan rumus sebagai berikut:

$$
\%=\frac{\bar{x}}{\Sigma x} \times 100 \% \text { dengan } \mathrm{X}=\frac{\text { Jumah.hasil.pengama } \tan }{\text { Jumlah.pengama } \tan }=\frac{P 1+P 2}{2}
$$

$$
\text { Dimana: } \quad \begin{array}{ll}
\frac{\%}{\mathrm{X}} & =\text { Presentase pengamatan } \\
\sum_{\mathrm{P}} \overline{\mathrm{X}} & =\text { Jumlah rata-rata } \\
\mathrm{P} 1 & =\text { Pengamat } 1 \\
\mathrm{P} 2 & =\text { Pengamat } 2
\end{array}
$$

\section{HASIL PENELITIAN}

\section{Hasil Analisis Item Butir Soal}

Validitas butir soal dimaksudkan untuk mengetahui kelayakan tes sehingga dapat digunakan sebagai instrument dalam penelitian ini. Dari perhitungan 40 soal diperoleh 15 soal tidak valid dan 25 soal valid. Hasil dari validitas soal-soal dirangkum dalam tabel D.1

Tabel D.1 Soal Valid dan Tidak Valid Tes Formatif Siswa

\begin{tabular}{|cc|}
\hline Soal Valid & Soal Tidak Valid \\
\hline $3,5,6,8,9,11,13,14,17,18,19,20,22,24$, & $1,2,4,7,10,12,15,16$ \\
$25,26,27,29,32,34,36,37,38,39,40$ & $21,23,28,30,31,33,35$ \\
\hline
\end{tabular}

Soal-soal yang telah memenuhi syarat validitas diuji reliabilitasnya. Dari hasil perhitungan diperoleh koefisien reliabilitas $r_{11}$ sebesar 0,877. Harga ini lebih besar dari harga $\mathrm{r}$ product moment. Untuk jumlah siswa $(\mathrm{N}=18)$ dengan $\mathrm{r}(95 \%)=0,444$. Dengan demikian soal-soal tes yang digunakan telah memenuhi syarat reliabilitas. Sedangkan analisis taraf kesukaran digunakan untuk mengetahui tingkat kesukaran soal. Hasil analisis menunjukkan dari 40 soal yang diuji terdapat: 7 soal dengan kriteria mudah, 21 soal kriteria sedang, dan 12 soal dengan kriteria sukar.

Analisis daya pembeda dilakukan untuk mengetahui kemampuan soal dalam membedakan siswa yang berkemampuan tinggi dengan siswa yang berkemampuan rendah. Dari hasil analisis daya pembeda diperoleh soal yang berkriteria jelek sebanyak 8 soal, berkriteria cukup 14 soal, dan berkriteria baik sejumlah 18 soal. Dengan demikian soal-soal tes yang digunakan telah memenuhi syara-syarat validitas, reliabilitas, taraf kesukaran, dan daya pembeda.

Vol. 9 No. 2, Juni 2017

Madrasah homepage: http://ejournal.uin-malang.ac.id/index.php/madrasah/index 


\section{MADRASAH}

Jurnal Pendidikan dan Pembelajaran Dasar

p ISSN: 1979-5599 | e ISSN: 2502-194X

P a g e

\section{Hasil Pengamatan Guru dan Siswa}

Berdasarkan pengamatan tampak bahwa aktivitas guru yang paling dominan pada siklus I yaitu membimbing dan mengamati siswa dalam menentukan konsep yaitu $25 \%$. Memberi umpan balik/evaluasi/tanya jawab $(16,6 \%)$, menjelaskan materi yang sulit $(11,7)$. Meminta siswa mendiskusikan dan menyajikan hasil kegiatan $(8,2 \%)$, dan membimbing siswa merangkum pelajaran $(6,7 \%)$. Sedangkan aktivitas siswa yang paling dominan pada siklus I adalah bekerja dengan sesama anggota kelompok yaitu (21\%). Mendengarkan/ memperhatikan penjelasan guru (17,9\%). Diskusi antar siswa/antara siswa dengan guru $(13,8 \%)$, membaca buku $(12,1 \%)$, mengerjakan tes evaluasi $(10,8 \%)$, menulis yang relevan dengan $\mathrm{KBM}(7,7 \%)$, merangkum pembelajaran (6,7\%). menanggapi/mengajukan pertanyaan/ide $(5,4 \%)$, dan menyajikan hasil pembelajaran $(4,6 \%)$,

Siklus II aktivitas guru yang paling dominan yaitu membimbing dan mengamati siswa dalam menemukan konsep yaitu $22,6 \%$, sedangkan aktivitas menjelaskan materi yang sulit dan memberi umpan balik/evaluasi/tanya jawab menurun masing-masing sebesar $(10 \%)$, dan $(11,7 \%)$. Aktivitas lain yang mengalami peningkatan adalah mengkaitkan dengan pelajaran sebelumnya (10\%), menyampiakan materi/strategi/langkah-langkah (13,3\%), meminta siswa menyajikan dan mendiskusikan hasil kegiatan $(10 \%)$, dan membimbing siswa merangkum pelajaran (10\%). Adapun aktivitas yang tidak menglami perubahan adalah menyampaikan tujuan $(6,7 \%)$ dan memotivasi siswa (6,7\%). Sedangkan untuk aktivitas siswa yang paling dominan pada siklus II adalah bekerja dengan sesama anggota kelompok yaitu (22,1\%) dan mendengarkan/memperhatikan penjelasan guru (20,8\%), aktivitas yang mengalami peningkatan adalah membaca buku siswa $(13,1 \%)$ dan diskusi antar siswa/antara siswa dengan guru (15,0\%). Sedangkan aktivitas yang lainnya mengalami penurunan.

Penilaian pada siklus I yang diberikan pengamat yaitu cukup baik dengan rata-rata sebesar 39,50. Beberapa aspek yang perlu mendapatkan perhatian yaitu: memotivasi siswa, menghubungkan dengan pelajaran sebelumnya, dan pengelolaan waktu. Sedangkan siklus II guru mendapatkan penilaian baik dari pengamat meliputi membimbing siswa dalam melakukan kegiatan PBM, mempresentasikan langkah-langkah model pembelajaran active learning tipe pengadilan majelis hakim, serta antusiasme kelas baik guru maupun siswa, dengan rata-rata hasil penilaian 48,50.

\section{Hasil Nilai Tes Formatif Siswa}

Pelaksanaan siklus I nilai rata-rata prestasi belajar siswa adalah79,56 dan ketuntasan belajar 77,78 \% atau ada 14 siswa dari 18 siswa sudah tuntas belajar. Hasil ini menunjukkan bahwa pada siklus I ini ketuntasan belajar secara klasikal telah mengalami peningkatan sedikit lebih baik dari prasiklus. Hal ini disebabkan karena (1) siswa masih merasa baru dan belum mengerti apa yang dimaksudkan dan digunakan guru dengan menerapkan model pembelajaran active learning tipe pengadilan majelis hakim; (2) guru menginformasikan bahwa setiap akhir pelajaran akan selalu diadakan tes formaif sehingga pada pertemuan berikutnya siswa lebih termotivasi untuk belajar; (3) Pemahaman siswa sudah mulai mengerti apa yang dimaksudkan dan diinginkan guru dengan menerapkan model pembelajaran active learning tipe pengadilan mejelis hakim.

Siklus II diperoleh nilai rata-rata tes formatif sebesar 86,00 dan terlihat sebanyak 17 siswa mencapai ketuntasan belajar. Maka secara klasikal ketuntasan belajar yang telah tercapai sebesar $94,44 \%$ (termasuk kategori tuntas). Hasil pada siklus II ini mengalami peningkatan lebih baik dari siklus I. Adanya peningkatan hasil belajar pada siklus II ini

Vol. 9 No. 2, Juni 2017

Madrasah homepage: http://ejournal.uin-malang.ac.id/index.php/madrasah/index 
dipengaruhi oleh adanya peningkatan kemampuan guru dalam menerapkan model pembelajaran active learning tipe pengadilan majelis hakim membuat siswa menjadi lebih terbiasa dengan pembelajaran seperti ini sehingga siswa lebih mudah dalam memahami materi yang telah diberikan. Secara rinci dapat dilihat pada grafik 1.2 di bawah ini.

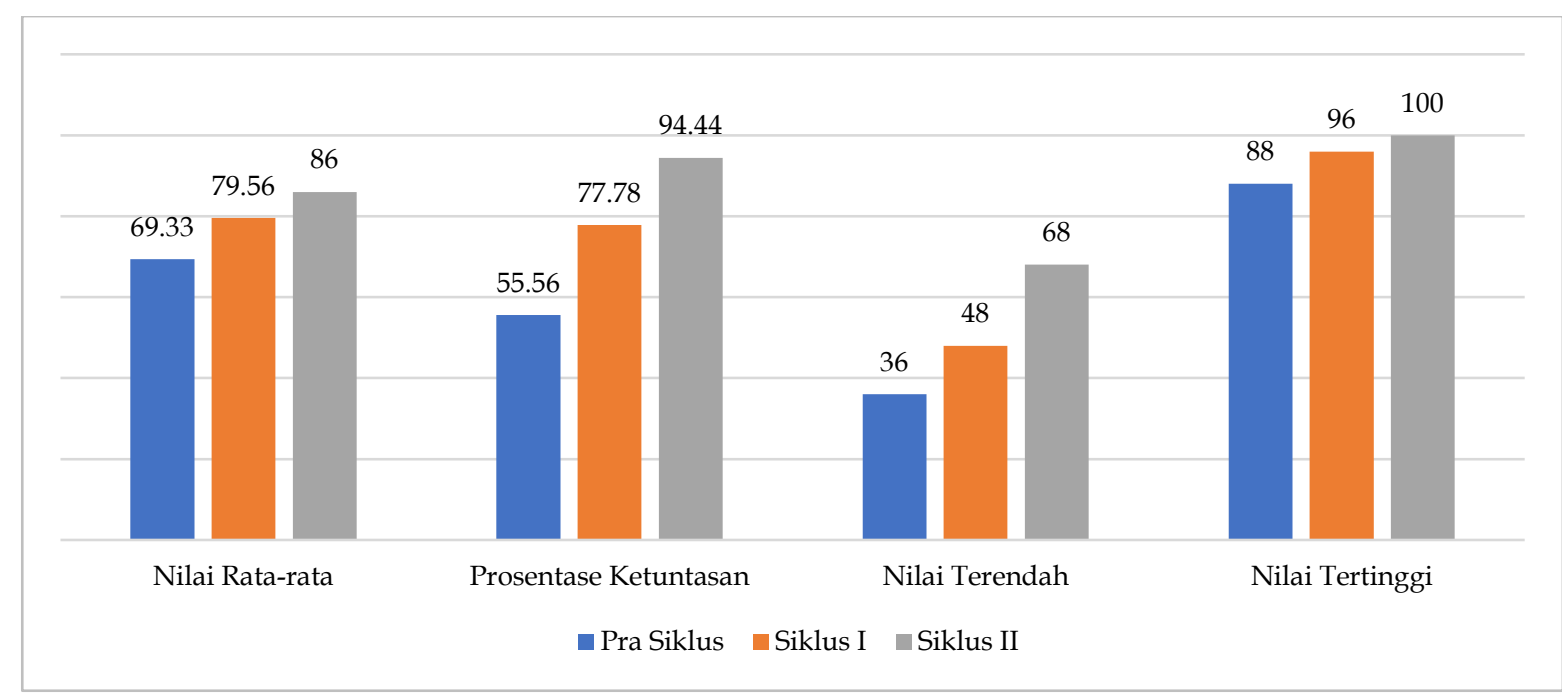

Grafik D.1 Hasil Nilai Tes Formatif Siswa Tiap Kelas

\section{Hubungan Antar Siklus}

Berdasarkan perbandingan data evaluasi yang diperoleh selama penelitian dilakukan, bahwa hasil belajar siswa mengalami peningkatan secara signifikan. Hal ini dibuktikan dengan adanya peningkatan nilai kemampuan memahami narkoba dan pelecehan seksual setelah tindakan yang meliputi siklus I dan siklus II seperti tabel berikut.

Tabel D.1 Data Perbandingan Distributif Frekuensi

\begin{tabular}{|ccccc|}
\hline \multirow{2}{*}{ No } & \multirow{2}{*}{ Interval Kelas } & \multicolumn{3}{c|}{ Frekuensi } \\
\cline { 3 - 5 } & & Prasiklus & Siklus I & Siklus II \\
\hline 1. & $\leq 69$ & 8 & 4 & 1 \\
\hline 2. & $70-74$ & 2 & 1 & 0 \\
\hline 3. & $75-79$ & 2 & 2 & 3 \\
\hline 4. & $80-84$ & 4 & 6 & 5 \\
\hline 5. & $85-89$ & 2 & 2 & 4 \\
\hline 6. & $90-94$ & 0 & 1 & 1 \\
\hline 7. & $95-100$ & 0 & 2 & 4 \\
\hline
\end{tabular}

Dari tabel distributif frekuensi di atas, terlihat adanya peningkatan frekuensi nilai siswa di atas KKM yaitu 70. Jumlah siswa yang mendapatkan nilai di atas KKM meningkat dari prasiklus, siklus I dan siklus II. Sedangkan dari hasil perbandingan frekuensi nilai di atas dapat dibuat grafik perbandingan sebagai berikut ini:

Vol. 9 No. 2, Juni 2017

Madrasah homepage: http://ejournal.uin-malang.ac.id/index.php/madrasah/index 


\section{MADRASAH}

Jurnal Pendidikan dan Pembelajaran Dasar

p ISSN: 1979-5599 | e ISSN: 2502-194X

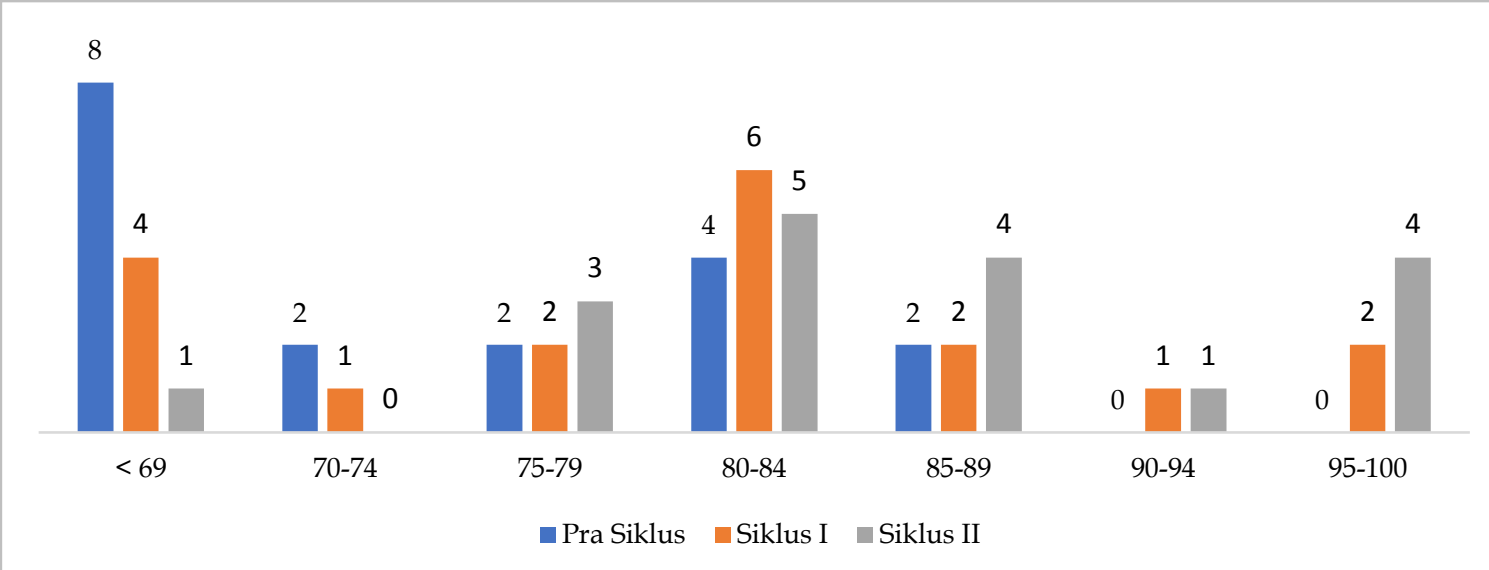

Grafik D.2 Perbandingan Kemampuan Memahami Materi Narkoba \& Pelecehan Seksual

Berdasarkan tabel dan grafik perbandingan di atas dapat dilihat adanya hubungan antar siklus yaitu mengenai kemampuan memahami narkoba dan pelecehan seksual yang semakin meningkat dari sebelum tindakan hingga sesudah tindakan. Peningkatan tersebut terjadi karena dilaksanakan pembelajaran PJOK melalui model pembelajaran active learning tipe pengadilan majelis hakim yang semakin baik dari siklus ke siklus. Hubungan peningkatan kemampuan memahami narkoba dan pelecehan seksual antar siklus dapat dibuktikan melalui hasil yang dijabarkan berikut ini: siklus I siswa yang memperoleh nilai pada kelas interval $\leq 69$ ada 4 siswa, 70-74 ada 1 siswa, 75-79 ada 2 siswa, 80-84 ada 6 siswa, 85-89 ada 2 siswa dan 90-94 ada 1 siswa, dan 95-100 ada 2 siswa. Sedangkan pada siklus II yang memperoleh nilai pada kelas interval interval $\leq 69$ ada 1 siswa, 70-74 tidak ada siswa, 75-79 ada 3 siswa, 80-84 ada 5 siswa, 85-89 ada 4 siswa dan 90-94 ada 1 siswa, dan 95-100 ada 4 siswa.

\section{E. PENUTUP}

\section{Simpulan}

Berdasarkan hasil penelitian tindakan kelas yang dilaksanakan dalam dua siklus tersebut diketahui bahwa dengan model pembelajaran active learning tipe pengadilan majelis hakim dapat meningkatkan kemampuan memahami materi narkoba dan pelecehan seksual pada siswa kelas VI SDN Tanggulangin I, tahun pelajaran 2015/2016. Hal ini terbukti pada prasiklus nilai rata-rata kelas 69,33 dengan ketuntasan klasikal yang hanya mencapai $55,56 \%$. Kondisi tersebut mengalami peningkatan, pada siklus I, dimana nilai rata-rata kelas menjadi 79,56 dengan ketuntasan klasikal 77,78\%, dan siklus II nilai rata-rata kelas menjadi 86,00 dengan ketuntasan klasikal 94,44\%. Dengan demikian penerapan model pembelajaran active learning tipe pengadilan majelis hakim dapat dilaksanakan untuk meningkatkan kualitas pembelajaran PJOK pokok bahasan narkoba dan pelecehan seksual di kelas VI SDN Tanggulangin I sehingga dapat meningkatkan kemampuan memahami narkoba dan pelecehan seksual bagi siswa

\section{Saran}

Dari hasil penelitian yang diperoleh agar proses belajar mengajar PJOK lebih efektif dan lebih memberikan hasil yang optimal bagi siswa, maka disampaikan saran sebagai berikut: (1) Untuk melaksanakan model pembelajaran active learning tipe pengadilan majelis hakim memerlukan persiapan yang cukup matang, sehingga guru harus mampu

Vol. 9 No. 2, Juni 2017

Madrasah homepage: http://ejournal.uin-malang.ac.id/index.php/madrasah/index 
menentukan atau memilih topik yang benar-benar bisa diterapkan dengan model pembelajaran active learning tipe pengadilan majelis hakim dalam proses belajar mengajar sehingga diperoleh hasil yang optimal; (2) Dalam rangka meningkatkan prestasi belajar siswa, guru hendaknya lebih sering melatih siswa dengan berbagai model pembelajaran, walau dalam taraf yang sederhana, dimana siswa nantinya dapat menemukan pengetahuan baru, memperoleh konsep dan keterampilan, sehingga siswa berhasil atau mampu memecahkan masalah-masalah yang dihadapinya; (3) Perlu adanya penelitian yang lebih lanjut, karena hasil penelitian ini hanya dilakukan di kelas VI SDN Tanggulangin I semester genap tahun pelajaran 2015/2016; dan (4) Untuk penelitian yang serupa hendaknya dilakukan perbaikan-perbaikan agar diperoleh hasil yang lebih baik.

\section{REFERENSI}

Abu Achmadi dan Widodo S. (2004). Psikologi Belajar. Jakarta: Rineka Cipta

Dalyono, M. (1997). Psikologi Pendidikan. Jakarta: Rineka Cipta.

Departemen Pendidikan Nasional. (1995). Kamus Besar Bahasa Indonesia. Jakarta: Balai Pustaka, Edisi ketiga.

Departemen Pendidikan Nasional. (2004). Kurikulum Tingkat Satuan Pendidikan SD dan MI. Jakarta: Depdiknas

Djamarah, Syaiful Bahri. (1994). Prestasi Belajar Dan Kompetensi Guru. Surabaya: Usaha Nasional.

Hadari, Nawawi. (1981). Metode-Metode Mengajar. Jakarta: Pustaka Pelajar.

Iskandarwassid dan Dadang Sunendar. (2009). Strategi Pembelajaran Bahasa. Bandung: Remaja Rosdakarya.

Marimba. (1978). Psikologi Perkembangan. Jakarta: Aksara Baru.

Muhibbin Syah. (2000). Psikologi Pendidikan. Bandung: PT Remaja Rosda Karya.

Permendiknas No.22 Tahun 2006. Tentang Standar Isi.

Rusli, Lutan. (2009). Olahraga Dan Etika Fair Play. Dirjen Olahraga. Jakarta: Departemen Pendidikan Nasional

Sadly. (1977). Interaksi dan Motivasi Belajar Mengajar. Jakarta: Bina Aksara.

Sardiman, A.M. (2000). Interaksi \& Motivasi Belajar Mengajar. Jakarta: PT Raja Grafindo Perkasa.

Slameto. (2003). Belajar dan Faktor-faktor yang Mempengaruhinya. Jakarta: PT Rineka Cipta

Sugiarti, Titik. (1997). Penelitian Tindakan Kelas. Makalah disampaikan pada Pelatihan Peningkatan Kualifikasi Guru S1 PGSD. Universitas Jember

Sukintaka. (1992). Teori Bermain Untuk D.2 PGSD Penjaskes. Depdikbud Dirjen Dikti Proyek Pembinaan Tenaga Kependidikan.

Sunarto. (1996). Teori-Teori Belajar. Jakarta: Erlangga.

Trianto. (2010). Mendesain Model Pembelajaran Inovatif-Progresif: Konsep, Landasan, dan Implementasinya pada Kurikulum Tingkat Satuan Pendidikan (KTSP). Jakarta: Kencana Prenada Media Group.

Wasty, Soemanto. (1990). Psikologi Pendidikan. Jakarta: Rineka Cipta.

W.J.S. Poerwadarminta. (2002). Kamus Besar Bahasa Indonesia. Jakarta: Balai Pustaka

Vol. 9 No. 2, Juni 2017

Madrasah homepage: http://ejournal.uin-malang.ac.id/index.php/madrasah/index 